\title{
Oil refinery site may be home to ancient relics
}

Rex Dalton, Yuma

Plans to build the first oil refinery in the United States for nearly 30 years are heading for trouble over claims that the intended site may harbour important Native American archaeology.

The site is in the Gila River valley in Yuma county, Arizona, and is part of 22,600 hectares currently owned by the US Bureau of Reclamation. The region served as a major route across the Sonora Desert for centuries before the railroads were built.

Archaeological surveys have identified lots of finds in the valley - from rock paintings to former dwelling locations — that might help answer intriguing questions about life in an environmentally lush desert passage. "Archaeologists have long been interested in the valley," says Jeffrey Altschul, an archaeologist at Statistical Research, a Tucson-based consultancy.

The reclamation bureau is in the process of transferring the 22,600 hectares to the Wellton-Mohawk Irrigation and Drainage District. The district then plans to sell 1,200 hectares of it to Phoenix-based Arizona Clean Fuels, for construction of the \$2.5billion oil refinery.

No archaeological sites have been identified on the proposed site for the refinery, officials say, because it hasn't been surveyed yet.

As required by law, the bureau hires archaeologists to examine public land that is going to be sold or transferred, to ensure that important sites are charted for protection. But the irrigation district has pushed to

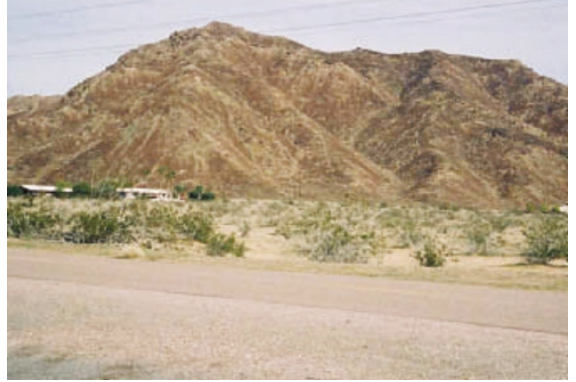

Building site: the Gila River valley could house the first US oil refinery to be built for decades.

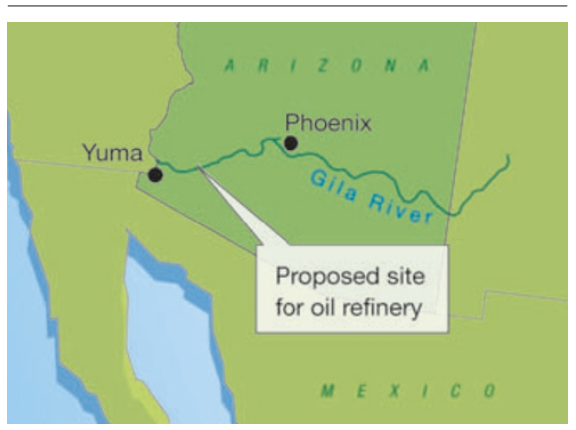

speed up the deal before archaeological studies are complete so that it can sell the land for the refinery.

Given the high financial stakes and Arizona's history of building over archaeological sites, community watchdog groups and Native American tribes are expressing concerns about the plan. "People need to take a hard look at what is going on," says Steve Brittle, who runs Don't Waste Arizona, a Phoenix-based environmental group.
Brittle and other critics fear that the bureau may buckle under commercial and political pressure, and transfer the land too quickly. Bureau officials in Yuma and Washington say that they are following all legal requirements, and will continue to do so.

The handling of the site could set a precedent for other sell-offs, as the bureau seeks to dispose of several sites in the western United States. The Gila River transfer is one of about 16 currently being undertaken by the bureau — and the first known to contain important archaeological remains.

Archaeological studies are now just getting under way on a larger land transfer of 33,200 hectares of the Humboldt River basin in northern Nevada, for example. Initial analysis indicates that these lands may also include significant archaeological sites.

The bureau will release a more comprehensive analysis of the Arizona site early next year. Native American tribes pushed for a more in-depth investigation after claiming that a 2002 government study wasn't sufficiently comprehensive.

But irrigation-board officials are becoming frustrated with the length of time taken to do the studies, and they are considering giving up on their plans for some of the archaeologically sensitive lands, so that they can secure the sale of the refinery tract.

This week in Yuma, the county government was expected to take the first step towards granting permission for the refinery project, which is also expected to draw opposition on environmental grounds.

\section{Frenchman is most thanked computer scientist}

\section{Declan Butler, Paris}

Who is Olivier Danvy? He is the most thanked person in computer science, according to an analysis of acknowledgements on nearly a third-of-a-million scientific papers.

The analysis, published this week, marks the debut of text-mining software from the lab of Lee Giles, a computer scientist at Pennsylvania State University.

The software opens up a largely untapped mine of information about how scientists and agencies affect all fields of science, says Jon Kleinberg, a computer scientist at Cornell University in Ithaca, New York. "Something that once seemed like it would require an enormous amount of manual labour has suddenly become feasible," he says.

Giles used the program to extract data on who had thanked whom in 335,000 papers in his lab's CiteSeer archive of computer-science papers (C. L. Giles and
I. G. Councill Proc. Natl Acad. Sci. USA 101, 17599-17604; 2004). The results reveal the people and funding agencies who received the most thanks in computer science.

Research on acknowledgements has been hampered by the lack of a data repository to study, says Kleinberg, contrasting this with citation statistics, which have been compiled manually for more than four decades by Thomson ISI in Philadelphia.

Acknowledgements are more arbitrary than citations. "Peer review always requires you to incorporate the latest and relevant citations. But no one is checking whether all contributors are referenced in the acknowledgements," says Erik van Mulligen, chief technology officer at Collexis, a text-mining company in Geldermalsen, the Netherlands.

Social scientists have already looked into the problem. They have broken acknowledgements into six main types, including support from funders, and the 'conceptual' support provided by scientists such as Danvy.

Eugene Garfield, founder of ISI, agrees that the various types of acknowledgement need to be categorized with care. "Otherwise you'll get quite a mishmash," he says.

Danvy, a French researcher who works on programming languages at the University of Aarhus in Denmark, says he was "stunned to find my name at the top of the list". After reflection, he put it down to a "series of coincidences" - he is multidisciplinary, well travelled, runs an international $\mathrm{PhD}$ programme, is a networker and belongs to a university department with a long tradition of having many international visitors.

"It's a snowball effect," says Danvy, who admits to being a helpful sort of fellow. "I encourage people a lot, and I advise many students on their papers." 